\title{
PENGEMBANGAN BAHAN AJAR ELEKTRONIK BERMUATAN MULTIMEDIA UNTUK SISWA SEKOLAH DASAR KELAS IV DI KABUPATEN NGADA
}

\author{
Maria Angelina Seso \\ STKIP Citra Bakti, Nusa Tenggara Timur, Indonesia \\ Email: maria.angelina.seso26@gmail.com \\ Dek Ngurah Laba Laksana \\ STKIP Citra Bakti, Nusa Tenggara Timur, Indonesia \\ Email:laba.laksana@citrabakti.ac.id \\ Konstatinus Dua \\ STKIP Citra Bakti, Nusa Tenggara Timur, Indonesia \\ Email: konstantinusdua@gmail.com
}

\begin{abstract}
The aimed of this research was to find out the result of electronic learning material containing multimedia on theme "Indahnya Kebersamaan" which appropriate with the characteristic of grade IV Elementary school students in Ngada regency. The subject of this research was Curriculum 2013 and Elementary school students of grade IV in Ngada regency while the object of this research was the content and the context of Ngada society local wisdom which relevance integrated into theme "Indahnya Kebersamaan" of grade IV to be an electronic learning material containing multimedia. The development of electronic learning material used model ADDIE (analyze, design, development, implementation, and evaluation). The result of research on the development of electronic learning material containing multimedia based on expert try out and students as product user as follows. (1) Try out on designer expert, being in very good category. (2) Try out on multimedia expert showed good category. (3) Try out on content expert showed good category. (4) Try out on students showed very good category. Then the result of research showed that electronic learning material developed deserves to be used for elementary school students of grade IV.
\end{abstract}

Keywords: electronic learning material, multimedia, thematic

\begin{abstract}
Abstrak
Penelitian ini bertujuan untuk menghasilkan bahan ajar elektronik bermuatan multimedia pada tema indahnya kebersamaan yang sesuai dengan karakteristik siswa sekolah dasar kelas IV di Kabupaten Ngada. Subjek dalam penelitian ini adalah kurikulum 2013 dan siswa SD kelas IV di Kabupaten Ngada sedangkan objek penelitian adalah konten dan konteks kearifan lokal masyarakat Ngada yang relevan diintegrasikan dalam tema indahnya kebersamaan kelas IV untuk dijadikan sebuah bahan ajar elektronik bermuatan multimedia. Pengembangan bahan ajar elektronik menggunakan model ADDIE (analyze, design, development, implementation, dan evaluation). Hasil pengembangan bahan ajar elektronik bermuatan multimedia berdasarkan uji coba ahli dan siswa sebagai pengguna produk adalah sebagai berikut. (1) Uji coba pada ahli desain, ada pada kategori sangat baik. (2) Uji ahli multimedia menunjukkan kategori baik. (3) Uji coba ahli konten menunjukkan kategori baik. (4) Uji coba pada siswa menunjukkan kategori sangat baik. Dengan demikian hasil penelitian menunjukkan bahwa bahan ajar elektronik yang dikembangkan layak digunakan pada siswa kelas IV.
\end{abstract}

Kata-kata Kunci: bahan ajar elektronik, multimedia, tematik

\section{Pendahuluan}

Pembelajaran tematik lebih menekankan pada penerapan konsep belajar sambil melakukan sesuatu (learning by doing). Oleh karena itu guru perlu mengemas atau merancang pengelaman belajar yang akan mempengaruhi kebermaknaan belajar pebelajar. Pengelaman belajar yang menunjukan kaitan unsur-unsur konseptual menjadikan konsep pembelajaran lebih efektif. Kaitan koseptual antra mata pelajaran yang dipelajari akan membentuk skema, sehingga pebelajar akan memperoleh keutuhan dan kebulatan pengetahuan. Selain itu dengan penerapan pembelajaran tematik di sekolah dasar akan membantu pebelajar, karena sesuai dengan tahap perkembangannya pebelajar yang masih melihat segala sesuatu sebagai suatu keutuhan (Dasna, dkk 2015).

Dalam Permendikbud Nomor 20 Tahun 2016 ditegaskan bahwa dalam proses pembelajaran, guru harus menyusun bahan ajar yang kontekstual sesuai dengan kebutuhan dan lingkungan masyarakat di mana siswa belajar. Laksana dan Widiastika (2017) mengungkapkan dalam temuanya bahwa masih banyak guru yang menggunakan bahan ajar yang sudah jadi seperti dalam buku Tematik yang telah disediakan oleh pemerintah ataupun LKS yang merupakan hasil dari suatu penerbit yang tidak sesuai dengan lingkungan di mana siswa tersebut belajar. Kondisi ini tentunya dapat mempersulit siswa dalam memahami materi yang seharusnya mereka kuasai. Bahan ajar cetak 
kurang mengedepankan unsur lingkungan dan budaya lokal masyarakat setempat. Guru sebagai pendidik yang profesional harus mampu menyiapkan media ajar yang memperhatikan kondisi lingkungan dan budaya masyarakat setempat dan mengakomodasi teknologi pembelajaran. Selain itu, penggunaan bahan ajar jadi ini, tidak mengedepankan unsur budaya lokal. Padahal unsur ini sangat penting untuk dimasukkan ke dalam proses pembelajaran melalui penyusunan bahan ajar yang memiliki konten budaya lokal.

Bahan ajar lokal dapat diintegrasikan ke dalam bahan ajar elektronik. Bahan ajar elektronik maupun cetak berisikan susunan materi pembelajaran yang sistematis baik tertulis maupun tidak tertulis untuk membelajarkan siswa dalam upaya mencapai tujuan pembelajaran. Bahan ajar elektronik menjadi pilihan tepat bagi para siswa sebagai sumber belajar. Pada era digital seperti saat ini, para siswa mulai jarang untuk membuka apalagi membaca buku konvensional. Kemudahan akses informasi dengan teknologi informasi dan komunikasi menjadi penyebabnya. Kemudahan akses informasi menurut Wulandari (Susanto, dkk 2016) berdampak pada generasi yang dibesarkan dalam masyarakat yang didominasi penggunaan teknologi informasi diberbagai bidang.

Susanto, dkk (2016) menyatakan bahwa bahan ajar elektronik yang dikembangkan dengan mengintegrasikan berbagai format teks dapat menjadi alternatif bahan ajar dengan fungsi yang beragam sehingga dapat disebut buku pintar elektronik. Bahan ajar elektronik lebih mudah untuk mengisi atau mengintegrasikan teks, gambar, maupun video. Bahan ajar elektronik memungkinkan untuk memasukan teks yang sangat berkaitan erat dengan multimedia (Utami \& Nugroho 2013).

Multimedia merupakan suatu media yang dikombinasikan dari berbagai unsur seperti teks, foto, seni grafis, suara, animasi, dan video yang dilengkapi dengan alat pengontrol yang dapat dioperasikan oleh pengguna sehingga pengguna dapat memilih apa yang dikehendaki dalam multimedia tersebut. Penggunaan multimedia dalam proses pembelajaran bertujuan untuk menyampaikan materi pembelajaran kepada siswa sehingga tujuan pembelajaran dapat tercapai (Prayogo, 2015).

Pemanfaatan multimedia dalam pembelajaran tematik dapat diajarkan dengan menggunakan media berbasis budaya lokal yang sesuai dengan materi yang akan diajarkan, misalkan pada pelajaran IPA, IPS dan Penjas. Salah satu karakteristik dari pembelajaran tematik menurut (Dasna, dkk 2015: 3.46) adalah bersifat fleksibel artinya dimana guru dapat mengaitkan bahan ajar dari satu mata pelajaran dengan mata pelajaran yang lainnya, bahkan mengaitkannya dengan kehidupan pebelajar dan keadaan lingkungan dimana sekolah dan pebelajar berada. Keadaan lingkungan yang dimaksud tersebut adalah salah satunya budaya lokal setempat.

Dalam pembelajaran berbasis budaya, budaya menjadi sebuah media bagi siswa untuk mentransformasikan hasil observasi mereka ke dalam bentuk prinsip-prinsip yang kreatif tentang alam. Dengan demikian, melalui pembelajaran berbasis budaya, siswa bukan sekedar meniru dan/atau menerima saja informasi yang disampaikan, tetapi siswa menciptakan makna dan pemahaman dari informasi yang diperolehnya. Demikian juga, pembelajaran berbasis budaya bukan sekedar mentransfer atau menyampaikan budaya atau perwujudan budaya, tetapi menggunakan budaya untuk menjadikan siswa mampu menciptakan makna, menembus batas imajinasi, dan kreativitas untuk mencapai pemahaman yang mendalam tentang materi subyek yang dipelajarinya (Laksana, dkk 2015).

\section{Metode Penelitian}

Penelitian ini merupakan penelitian pengembangan. Bahan ajar elektronik yang dikembangkan dengan menggunakan model ADDIE. Model ini terdiri atas lima langkah yaitu, (1) analyze, (2) design, (3) development, (4) implementation, dan (5) evaluation (Anglada, 2007). Pemilihan model ini didasari atas pertimbangan bahwa model ini dikembangkan secara sistematis dan berpijak pada landasan teoretis desain pembelajaran. Model ini disusun secara terprogram dengan urutan-urutan kegiatan yang sistematis dalam upaya pemecahan masalah belajar yang berkaitan dengan sumber belajar yang sesuai dengan kebutuhan dan karakteristik peserta didik.

Pengumpulan data dalam penelitian ini dengan cara memberikan kuisoner kepada para ahli dan siswa sebagai pengguna produk. Data yang telah dikumpulkan dalam penelitian dianalisis secara deskriptif kualitatif sebagai berikut, (1) data mengenai kualitas bahan ajar elektronik bermuatan multimedia berdasarkan kuisoner yang telah diberikan kepada para ahli dan siswa sebagai pengguna produk, dianalisis secara deskriptif kualitatif. Teknik analisis ini dilakukan dengan mengelompokan informasi yang berupa masukan, kritik dan saran perbaikan yang terdapat pada angket. Hasil analisis kemudian digunakan sebagai bahan untuk merevisi produk yang dikembangkan. (2) data mengenai kualitas bahan ajar elektronik bermuatan multimedia berdasarkan uji coba produk dianalisis melalui konversi skor yang didapat dari lembar kuisoner. Pengubahan hasil penilaian dari ahli dan siswa dari bentuk kualitatif kedalam bentuk kuantitatif skala 5. Produk yang dikembangkan dalam penelitian ini mencapai kriteria minimal validitas yang dicapai adalah kriteria baik. 


\section{Tahap Analyze (Analisis)}

\section{Hasil Penelitian dan Pembahasan}

Pada tahap analisis hal-hal yang dianalisis adalah silabus kelas IV pada tema "Indahnya Kebersamaan" yang mendiskripsikan konten dan konteks budaya lokal Ngada yang dapat dintegrasikan ke dalam bahan ajar elektronik yang dikembangkan.

\section{Tahap Design (Desain)}

Pada tahap desain peneliti mengembangkan bahan ajar dengan menggunakan refrensi buku tematik kelas IV yang bertema "Indahnya Kebersamaan" yang telah disediakan oleh pemerintah, lalu dibuat ke dalam bentuk draf bahan ajar yang dirancang pada microsoft word, kemudian mencari gambar-gambar yang bersifat kontekstual yang berkaitan dengan materi untuk digunakan dalam pengembangan bahan ajar yang dikembangkan. Selain itu, peneliti juga membuat video-video untuk dimasukan kedalam bahan ajar sesuai dengan materi. Gambar maupun video yang diambil bersifat kontekstual dan berbasis budaya lokal.

\section{Tahap Development (Pengembangan)}

Pada tahap pengembangan, peneliti membahas tentang hasil pengembangan bahan ajar elektronik yang telah revisi oleh ahli. Hasil pengembangan bahan ajar elektronik bermuatan multimedia adalah sebagai berikut.

\section{1) Cover}

Cover adalah tampilan awal maupun tampilan akhir bahan ajar elektronik tersebut. Pada tampilan awal bahan ajar elektronik ini diisi gambar sekelompok anak SD yang sedang belajar, dan juga terdapat tulisan yaitu judul buku bahan ajar elektronik yaitu tema 1 "Indahnya Kebersamaan" untuk siswa sekolah dasar kelas IV, sedangkan tampilan akhir berisi tulisan "buku tematik elektronik Berdasarkan Kurikulum 2013, untuk SD kelas IV". Gambar tampilan cover buku elektronik yang dikembangkan dapat dilihat pada gambar berikut ini.

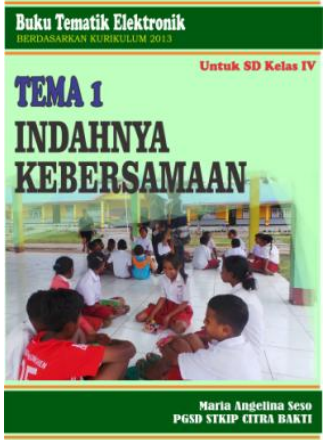

Gambar 1. Cover Depan

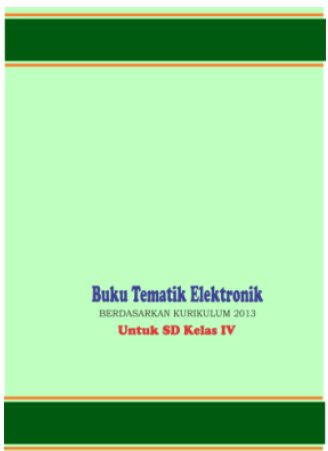

Gambar 2. Cover Belakang

\section{2) Panduan Penggunaan Bahan Ajar}

Panduan penggunaan bahan ajar ini berguna untuk memudahkan pengguna bahan ajar elektronik ini dalam memahami isi materi dari bahan ajar secara keseluruhan, kemudian guna menjelaskan cara menggunakan bahan ajar elektronik tersebut, sehingga memudahkan bagi pengguna bahan ajar elektronik ini.

3) Daftar Isi

Daftar isi berfungsi Memudahkan pengguna produk atau siswa dalam menentukan atau melihat nomor halaman pada sub tema mana dan halaman berapa yang akan mereka pelajari.

4) Jaringan Tema

Jaringan tema yang terdapat pada bahan ajar elektronik ini terdapat beberapa mata pelajaran yang ada dalam bahan ajar ini antara lain: Matematika, PPKn, Bahasa Indonesia, IPA, IPS, ISBdP dan PJOK, dan dilengkapi dengan kompetensi dasar serta indikator pembelajaran yang dibuat dalam bentuk bagan.

5) Subtema 1

Sub tema 1 tentang "Keberagaman Budaya Bangsaku". Pada Subtema 1 ini berisi tentang kegiatan pembelajaran dan kompetensi yang dikembangkan berupa pengetahuan, keterampilan dan sikap pada setiap pembelajaran.

\section{6) Pembelajaran 1}

Pembelajaran 1 pada bahan ajar elektronik ini terdapat pemetan indikator yang didalamnya ada empat mata pelajaran yang akan dipelajari oleh pengguna produk atau siswa yaitu, PPKn, SBdP, IPS dan Bahasa Indonesia. Selain itu juga ada tujuan pembelajaran yang harus dicapai oleh siswa. kemudian dalam pembelajaran 1 ada beberapa kegiatan yang harus dikerjakan oleh siswa yaitu kegiatan ayo mengamati, ayo bekerja sama, ayo belajar, ayo cari tau, ayo bernyanyi, ayo renungkan. Kegiatan mengamati siswa di minta untuk melihat peta budaya, dalam kegitan kerja sama siswa diminta untuk mengerjakan tugas berdasarkan soal latihan yang diberikan dalam bentuk kelompok, dalam kegiatan ayo cari tau siswa diminta untuk membaca isi teks yang 
sudah disediakan, ayo bernyanyi siswa diminta untuk menyanyikan lagu "Aku Anak Indonesia" sedangkan pada kegiatan ayo renungkan siswa diminta untuk merefleksi kembali apa yang telah dipelajari. Selain itu juga terdapat video lagu yang berjudul "Aku Anak Indonesia".

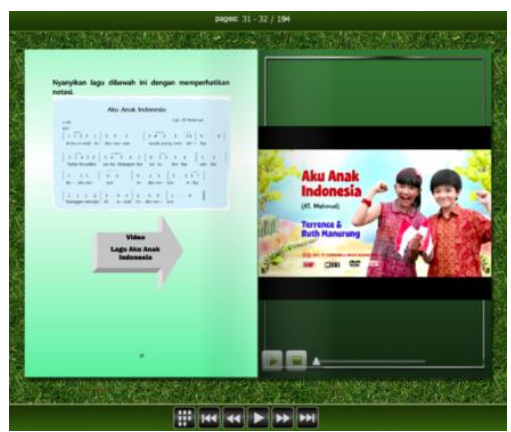

\section{7) Pembelajaran 2}

\section{Gambar 3. Tampilan Video Lagu Aku Anak Indonesia}

Pembelajaran 2 pada bahan ajar elektronik ini terdapat pemetan indikator yang dibuat dalam bentuk bagan didalamnya ada tiga mata pelajaran yaitu SBdP, Bahasa Indonesia dan Matematika. Selain itu juga ada tujuan pembelajaran yang harus dicapai oleh siswa. kemudian dalam pembelajaran 2 ada beberapa kegiatan yang harus dilakukan oleh siswa yaitu kegiatan ayo membaca, ayo berdiskusi, ayo berlatih, ayo renungkan dan bekerja sama dengan orang tua. Kegiatan membaca siswa diminta untuk membaca teks yang telah disediakan, ayo berlatih siswa diminta untuk mengerjakan soal-soal latihan yang telah disediakan, ayo berdiskusi siswa diminta untuk mendiskusikan teks yang telah dibaca, ayo renungkan siswa diminta untuk merefleksi kembali apa yang telah dipelajari dan bekerja sama dengan orang tua siswa diminta untuk mengerjakan tugas rumah bersama orang tua dirumah. Selain itu juga didalam pembelajaran 2 ini terdapat video tarian tradisional daerah Ngada yaitu tarian Ja'i.

\section{8) Pembelajaran 3}

Pembelajaran 3 pada bahan ajar elektronik ini terdapat pemetan indikator yang dibuat dalam bentuk bagan didalamnya ada tiga mata pelajaran yaitu PJOK, IPS, dan PPKn. Selain itu juga ada tujuan pembelajaran yang harus dicapai oleh siswa. kemudian dalam pembelajaran 3 ini ada beberapa kegiatan yang harus dikerjakan oleh siswa yaitu kegiatan ayo membaca, ayo diskusikan, ayo ceritakan, ayo renungkan dan kerja sama dengan orang tua. Ayo membaca siswa diminta untuk membaca teks bacaan yang telah disediakan, ayo diskusikan siswa diminta untuk berdiskusi dengan teman kelompok, ayo ceritakan siswa diminta untuk bercerita pengelamannya, ayo renungkan siswa diminta untuk merefleksikan kembali apa yang telah dipelajari. Selain itu juga didalam pembelajaran 3 ini terdapat video salah permainan tradisisonal Ngada yaitu permainan gasing.

\section{9) Pembelajaran 4}

Pembelajaran 4 pada bahan ajar elektronik ini terdapat pemetaan indikator yang dibuat dalam bentuk bagan didalamnya ada tiga mata pelajaran yaitu IPA, IPS dan PPKn. Selain itu juga ada tujuan pembelajaran yang harus dicapai oleh siswa. kemudian didalam pembelajaran 4 ada beberapa kegiatan yang harus dikerjakan oleh siswa yaitu kegiatan ayo membaca, ayo berlatih, ayo diskusikan, ayo ceritakan, ayo renungkan dan kerja sama dengan orang tua. Ayo membaca siswa diminta untuk membaca teks bacaan yang telah disediakan, ayo berlatih siswa diminta untuk mengerjakan soal-soal latihan, ayo diskusikan siswa diminta untuk berdiskusi dengan teman kelompok, ayo ceritakan siswa diminta untuk bercerita pengelamannya, ayo renungkan siswa diminta untuk merefleksikan kembali apa yang telah dipelajari, dan ayo kerja sama dengan orang tua siswa diminta untuk mengerjakan tugas rumah bersama dengan orang tua dirumah. Selain itu didalam pembelajaran 4 terdapat video alat musik tradisisonal.

\section{0) Pembelajaran 5}

Pembelajaran 5 pada bahan ajar elektronik ini terdapat pemetan indikator yang dibuat dalam bentuk bagan didalamnya ada empat mata pelajaran yaitu SBdP, Bahasa Indonesia, IPA dan Matematika. Selain itu juga ada tujuan pembelajaran yang harus dicapai oleh siswa. kemudian didalam pembelajaran 5 ada beberapa kegiatan yang harus dikerjakan oleh siswa yaitu kegiatan ayo mencoba, ayo menulis, ayo berkreasi, ayo renungkan dan kerja sama dengan orang tua. Kegiatan ayo mencoba siswa diminta untuk melakukan percobaan, ayo menulis siswa diminta untuk menulis laporan, ayo berkreasi siswa diminta untuk berkreasi dalam membuat kolase, ayo renungkan siswa diminta untuk merefleksi kembali apa yang telah dipelajari, ayo kerja sama dengan orang tua siswa diminta untuk mengerjakan tugas rumah bersama dengan orang tua dirumah.

\section{1) Pembelajaran 6}


Pembelajaran 6 pada bahan ajar elektronik ini terdapat pemetaan indikator yang dibuat dalam bentuk bagan didalamnya ada dua mata pelajaran yaitu Bahasa Indonesia dan Matematika. Selain itu juga ada tujuan pembelajaran yang harus dicapai oleh siswa. kemudian dalam pembelajaran 6 ada beberapa kegiatan yang harus dikerjakan oleh siswa yaitu kegiatan ayo membaca, ayo temukan jawaban, ayo berlatih, ayo renungkan dan kerja sama dengan orang tua. Ayo membaca siswa diminta untuk membaca teks bacaan yang telah disediakan, ayo temukan jawaban siswa diminta untuk mencari jawaban yang terdapat pada teks, ayo renungkan siswa diminta untuk merfleksikan kembali pelajaran yang telah dipelajari ayo kerja sama dengan orang tua siswa diminta untuk mengerjakan tugas rumah bersama dengan orang tua dirumah.

12) Subtema 2

Sub tema 2 tentang "Kebersamaan dalam Keberagaman". Pada Subtema 2 ini berisi tentang kegiatan pembelajaran dan kompetensi yang dikembangkan berupa pengetahuan, keterampilan dan sikap pada setiap pembelajaran.

13) Pembelajaran 1

Pembelajaran 1 pada bahan ajar elektronik ini terdapat pemetaan indikator yang dibuat dalam bentuk bagan didalamnya ada tiga mata pelajaran yaitu PJOK, PPKn dan Matematika. Selain itu juga ada tujuan pembelajaran yang harus dicapai oleh siswa. kemudian didalam pembelajaran 1 ini teradapat beberapa kegiatan yang harus dikerjakan oleh siswa yaitu kegiatan ayo amati, ayo ceritakan, ayo bekerja sama, ayo temukan jawaban, ayo renungkan, dan kerja sama dengan orang tua. Kegiatan ayo mengamati siswa diminta untuk mengamati gambar, ayo ceritakan siswa diminta untuk menceritakan pengelaman, ayo bekerja sama siswa diminta untuk bekerja kelompok, ayo renungkan siswa diminta untuk merefleksikan kembali pelajaran yang telah dipelajari, dan kerja sama dengan orang tua siswa diminta untuk mengerjakan tugas rumah bersama orang tua dirumah.

14) Pembelajaran 2

Pembelajaran 2 pada bahan ajar elektronik ini terdapat pemetan indikator yang dibuat dalam bentuk bagan didalamnya ada dua mata pelajaran yaitu Bahasa Indonesia dan IPS. Selain itu juga ada tujuan pembelajaran yang harus dicapai oleh siswa. kemudian didalam pemebelajarn 2 terdapat beberapa kegiatan yang harus dikerjakan oleh siswa yaitu kegiatan ayo berlatih, ayo lakukan, ayo renungkan, dan kerja sama dengan orang tua. Kegiatan ayo berlatih siswa diminta untuk mengerjakan soal-soal latihan, ayo lakukan siswa diminta untuk menukarkan hasil wawancara dengan teman sebangku, ayo renungkan siswa diminta untuk merefleksikan kembali pelajaran yang telah dipelajari, dan kerja sama dengan orang tua siswa diminta untuk mengerjakan tugas rumah bersama orang tua dirumah.

15) Pembelajaran 3

Pembelajaran 3 pada bahan ajar elektronik ini terdapat pemetaan indikator yang dibuat dalam bentuk bagan didalamnya ada tiga mata pelajaran yaitu SBdP, IPA dan Matematika. Selain itu juga ada tujuan pembelajaran yang harus dicapai oleh siswa. kemudian didalam pembelajaran 3 terdapat beberapa kegiatan yang harus dikerjakan oleh siswa yaitu kegiatan ayo mencoba, ayo bekerja sama, ayo lakukan, ayo renungkan, dan kerja sama dengan orang tua. Kegiatan ayo mencoba siswa diminta untuk melakukan percobaan, ayo bekerja sama siswa diminta untuk bekerja sama dengan teman kelompok, ayo lakukan siswa diminta untuk melakukan pengubinan, ayo renungkan siswa diminta untuk merefleksikan kembali pelajaran yang telah dipelajari, dan kerja sama dengan orang tua siswa diminta untuk mengerjakan tugas rumah bersama orang tua dirumah.

16) Pembelajaran 4

Pembelajaran 4 pada bahan ajar elektronik ini terdapat pemetaan indikator yang dibuat dalam bentuk bagan didalamnya ada dua mata pelajaran yaitu Bahasa Indonesia dan PPKn. Selain itu juga ada tujuan pembelajaran yang harus dicapai oleh siswa. Kemudian didalam pembelajaran 4 terdapat beberapa kegiatan yang harus dikerjakan oleh siswa yaitu kegiatan ayo lakukan, ayo cari tahu, ayo berlatih, ayo renungkan dan kerja sama dengan orang tua. Kegiatan ayo lakukan siswa diminta untuk bekerja sama dengan kelompok untuk menampilkan drama, ayo caru tau siswa diminta untuk mencari tahu tentang situs sejarah, ayo berlatih siswa diminta untuk mengerjaka soal-soal latihan, ayo renungkan siswa diminta untuk merefleksikan kembali pelajaran yang telah dipelajari, dan kerja sama dengan orang tua siswa diminta untuk mengerjakan tugas rumah bersama orang tua dirumah.

17) Pembelajaran 5

Pembelajaran 5 pada bahan ajar elektronik ini terdapat pemetaan indikator yang dibuat dalam bentuk bagan didalamnya ada dua mata pelajaran yaitu PJOK dan Matematika. Selain itu juga ada tujuan pembelajaran yang harus dicapai oleh siswa. Kemudian didalam pembelajaran 5 terdapat beberapa kegiatan yang harus dikerjakan oleh siswa yaitu kegiatan taukah kamu, ayo renungkan dan kerja sama dengan orang tua. Kegiatan taukah kamu siswa diminta untuk mencari tau bagaimana cara membulatkan sebuah bilangan, ayo renungkan siswa diminta untuk merefleksikan kembali pelajaran yang telah dipelajari, dan kerja sama dengan orang tua siswa diminta untuk mengerjakan tugas rumah bersama orang tua dirumah.

18) Pembelajaran 6 
Pembelajaran 6 pada bahan ajar elektronik ini terdapat pemetaan indikator yang dibuat dalam bentuk bagan didalamnya ada satu kegiatan yaitu evalusai. Selain itu juga ada tujuan pembelajaran yang harus dicapai oleh siswa. Kemudian dipembelajaran 6 terdapat beberapa kegiatan yang harus dikerjakan oleh siswa yaitu kegiatan ayo bekerja sama, ayo renungkan dan kerja sama dengan orang tua. Kegiatan ayo bekerja sama siswa diminta untuk bekerja sama dengan kelompok, ayo renungkan siswa diminta untuk merefleksikan kembali pelajaran yang telah dipelajari, dan kerja sama dengan orang tua siswa diminta untuk mengerjakan tugas rumah bersama orang tua dirumah.

19) Subtema 3

Sub tema 3 tentang "Bersyukur Atas Keberagaman". Pada Subtema 3 ini berisi tentang kegiatan pembelajaran dan kompetensi yang dikembangkan berupa pengetahuan, keterampilan dan sikap pada setiap pembelajaran.

20) Pembelajaran 1

Pembelajaran 1 pada bahan ajar elektronik ini terdapat pemetaan indikator yang dibuat dalam bentuk bagan didalamnya ada tiga mata pelajaran yaitu SBdP, Bahasa Indonesia dan IPS. Selain itu juga ada tujuan pembelajaran yang harus dicapai oleh siswa. Kemudian dalam pembelajaran 1 terdapat beberapa kegiatan yang harus dikerjakan oleh siswa yaitu kegiatan ayo membaca, ayo ceritakan, ayo mencoba, ayo renungkan dan kerja sama dengan orang tua. Kegiatan ayo membaca siswa diminta untuk membaca teks bacaan yang telah disediakan, ayo ceritakan siswa diminta untuk menceritakan kembali teks yang telah dibaca secara singkat, ayo mencoba siswa diminta untuk menuliskan kembali cerita dalam bahasa daerah, ayo renungkan siswa diminta untuk merefleksikan kembali pelajaran yang telah dipelajari, dan kerja sama dengan orang tua siswa diminta untuk mengerjakan tugas rumah bersama orang tua dirumah.

\section{1) Pembelajaran 2}

Pembelajaran 2 pada bahan ajar elektronik ini terdapat pemetaan indikator yang dibuat dalam bentuk bagan didalamnya ada empat mata pelajaran yaitu SBdP, Bahasa Indonesia, IPA dan Matematika. Selain itu juga ada tujuan pembelajaran yang harus dicapai oleh siswa. Kemudian didalam pembelajaran 4 terdapat beberapa kegiatan yang harus dikerjakan oleh siswa yaitu kegiatan ayo bernyanyi, ayo mencoba, ayo lakukan, ayo berlatih, dan ayo renungkan. Kegiatan ayo bernyanyi siswa diminta untuk bernyanyi lagu "O Doa" salah satu lagu daerah dari Kabupaten Ngada, ayo mencoba siswa diminta untuk melakukan percobaan, ayo lakukan siswa diminta untuk melakukan penaksiran, ayo berlatih siswa diminta untuk mengerjakan soal-soal latihan, ayo renungkan siswa diminta untuk merefleksikan kembali pelajaran yang telah dipelajari.

\section{2) Pembelajaran 3}

Pembelajaran 3 pada bahan ajar elektronik ini terdapat pemetaan indikator yang dibuat dalam bentuk bagan didalamnya ada empat mata pelajaran yaitu PPKn, IPS, Bahasa Indonesia dan Matematika. Selain itu juga ada tujuan pembelajaran yang harus dicapai oleh siswa. Kemudian didalam pembelajaran 3 terdapat dua kegiatan yang harus dikerjakan oleh siswa yaitu ayo ceritakan dan ayo renungkan. Ayo ceritakan siswa diminta untuk menceritakan salah satu makanan khas daerah yang sudah pernah dimakan dan ayo renungkan siswa diminta untuk merefleksikan kembali pelajaran yang telah dipelajari.

\section{3) Pembelajaran 4}

Pembelajaran 4 pada bahan ajar elektronik ini terdapat pemetaan indikator yang dibuat dalam bentuk bagan didalamnya ada tiga mata pelajaran yaitu PPKn, IPS dan Matematika. Selain itu juga ada tujuan pembelajaran yang harus dicapai oleh siswa. Kemudian didalam pembelajaran 4 terdapat beberapa kegiatan yang harus dikerjakan oleh siswa yaitu, kegiatan ayo bekerja sama, ayo berlatih, ayo renungkan dan kerja sama dengan orang tua. Kegiatan ayo bekerja sama siswa diminta untuk bekerja sama dengan teman kelompok, ayo berlatih siswa diminta untuk mengerjakan soal-soal latihan, ayo renungkan siswa diminta untuk merefleksikan kembali pelajaran yang telah dipelajari, dan kerja sama dengan orang tua siswa diminta untuk mengerjakan tugas rumah bersama orang tua dirumah.

\section{4) Pembelajaran 5}

Pembelajaran 5 pada bahan ajar elektronik ini terdapat pemetaan indikator yang dibuat dalam bentuk bagan didalamnya ada tiga mata pelajaran yaitu Bahasa Indonesia, IPA dan PJOK. Selain itu juga ada tujuan pembelajaran yang harus dicapai oleh siswa. Kemudian didalam pembelajaran 5 terdapat beberapa kegiatan yang harus dikerjakan oleh siswa yaitu, kegiatan ayo membaca, ayo mencoba, ayo menulis, ayo cari tahu dan ayo renungkan. Kegiatan ayo membaca siswa diminta untuk membaca teks bacaan yang telah disediakan, ayo mencoba siswa diminta untuk melakukan percobaan, ayo menulis siswa diminta untuk menuliskan hasil percobaan, ayo cari tahu siswa diminta untuk mencari tahu tentang pemantulan dan penyerapan bunyi, dan ayo renungkan siswa diminta untuk merefleksikan kembali pelajaran yang telah dipelajari.

\section{5) Pembelajaran 6}

Pembelajaran 6 pada bahan ajar elektronik ini terdapat pemetaan indikator yang dibuat dalam bentuk bagan didalamnya ada dua mata pelajaran yaitu SBdP, dan Matematika. Selain itu juga ada tujuan pembelajaran yang harus dicapai oleh siswa. kemudian dalam pembelajaran 6 terdapat beberapa kegiatan yang harus dikerjakan oleh siswa yaitu, kegiatan ayo bernyanyi, ayo diskusikan, ayo berlatih, ayo renungkan dan kerja 
sama dengan orang tua. Kegiatan Ayo bernyanyi siswa diminta untuk menyanyikan lagu "Syukur", ayo diskusikan siswa diminta untuk berdiskusi bersama dengan teman kelompok, ayo berlatih siswa diminta untuk mengerjakan soal-soal latihan, ayo renungkan siswa diminta untuk merefleksikan kembali pelajaran yang telah dipelajari dan kerja sama dengan orang tua siswa diminta untuk mengerjakan tugas rumah bersama dengan orang tua.

26) Daftar Pustaka

Daftar pustaka ini berisi tentang sumber yang dijadikan sebagai bahan refrensi dalam penyusunan atau pengembangan bahan ajar elektronik ini.

\section{Tahap Implementation (Implementasi)}

Pada tahap implementasi peneliti melakukan uji coba bahan ajar elektorik. Bahan ajar elektronik bermuatan multimedia akan dilakukan uji coba oleh ahli desain, ahli multimedia, ahli konten dan siswa sebagai pengguna bahan ajar. Hasil uji coba pada ahli desain, ada pada kategori sangat baik, dengan skor tertinggi pada aspek kemenarikan desain cover. Hasil uji ahli multimedia menunjukkan kategori baik, dengan skor tertinggi pada aspek dukungan terhadap materi, keserasian penyajian gambar/ilustrasi dan kemenarikan gambar/ilustrasi. Hasil uji coba ahli konten menunjukkan kategori baik, dengan skor tertinggi ada pada aspek kelengkapan materi, kesesuaian dengan indikator, dan kesesuaian dengan tujuan. Hasil uji coba pada siswa menunjukkan kategori sangat baik, dengan skor tertinggi ada pada aspek judul menarik dan mudah dibaca, kejelasan pemberian contoh, dan gambar mempermudah pemahaman materi.

\section{Tahap Evaluation (Evaluasi)}

Pada tahap evaluasi ini akan membahas perbaikan atau revisi oleh masing-masing ahli yang telah di uji coba berdasarkan saran atau komentar.

1) Revisi Ahli Desain

Penilaian bahan ajar elektronik oleh ahli desain pembelajaran ada pada kategori sangat baik ada pun saran maupun komentar yang diberikan oleh ahli desain pembelajaran untuk merevisi bahan ajar elektronik yang dikembangkan.

\section{2) Revisi ahli multimedia}

Penilaian bahan ajar elektronik oleh ahli multimedia ada pada kategori baik adapun saran maupun komentar yang diberikan oleh ahli multimedia untuk merevisi bahan ajar elektronik yang dikembangkan pada aspek cover di indikator pusat pandang, pengaturan jarak, konsistensi layout tata letak, pemilihan background, kualitas video, volume suara, kemudahan penggunaan bahan ajar elektronik.

\section{3) Revisi ahli konten}

Penilaian bahan ajar elektronik oleh ahli konten ada pada kategori baik adapun saran ataupun komentar yang diberikan oleh ahli konten untuk merevisi bahan ajar elektronik yang dikembangkan. Saran yang diberikan oleh ahli konten diminta perhatikan juga dengan kelengkapan sarana dan prasarana, tidak ada yang di revisi.

4) Revisi pengguna produk (siswa)

Penilaian bahan ajar elektronik oleh pengguna produk (siswa) ada pada kategori sangat baik adapun saran ataupun komentar yang diberikan oleh pengguna produk (siswa) untuk merevisi bahan ajar elektronik yang dikembangkan pada aspek kemenarikan tampilan bahan ajar elektronik secara keseluruhan.

Berdasarkan hasil penelitian yang telah diuji cobakan oleh peneliti bahwa dalam pengembangan bahan ajar elektronik ini melalui beberapa tahap berdasarkan model yang digunkan yaitu model ADDIE. Pada tahap pengembangan ada beberapa yang dikembangkan yaitu pengembangan panduan bahan ajar, jaringan tema, subsub tema, pemetaan indikator, kegiatan pembelajaran dan latihan-latihan soal.

Tahap pengembangan panduan bahan ajar yang dikembangkan bertujuan untuk memudahkan pengguna bahan ajar elektronik ini dalam memahami isi materi dari bahan ajar secara keseluruhan, kemudian guna menjelaskan cara menggunakan bahan ajar elektronik tersebut, sehingga memudahkan bagi pengguna bahan ajar elektronik ini. Jaringan tema yang terdapat dalam bahan ajar elektronik ini berisi tentang kompetensi dasar dan indikator yang harus dicapai oleh siswa, yang dibuat dalam bentuk bagan. Jaringan tema ini dibuat untuk satu tema yaitu tema "Indahnya Kebersamaan". Sub-sub tema yang terdapat didalam pengembangan bahan ajar elektronik ini berfungsi untuk mengetahui semua kegiatan pembelajaran maupun kompetensi yang dikembangkan dalam setiap pembelajaran baik pembelajaran 1 sampai pembelajaran 6. Pemetaan indikator dibuat untuk masing-masing pembelajaran yang didalamnya berisi tentang kompetensi dasar dan indikator yang dikembangkan untuk setiap pembelajaran baik pembelajaran 1 sampai pembelajaran 6. Kegiatan pembelajaran dalam pengembangan bahan ajar elektronik ini yang berisi kegiatan-kegiatan yang akan dilakukan oleh siswa selama pembelajaran berlangsung maupun kegiatan yang akan mereka lakukan dirumah bersama orang tua, yang terdapat dalam kegiatan pembelajaran yaitu kegiatan ayo membaca, ayo berlatih, ayo bercerita, ayo mencoba, ayo renungkan, ayo lakukan, dan kerja sama dengan orang tua. Latihan-latihan soal yang terdapat didalam pengembangan bahan ajar elektronik ini berfungsi bagi siswa untuk mengukur kemampuan siswa atapun membantu siswa dalam memahami materi yang mereka pelajari. 
Kehadiran bahan ajar elektronik ini diharapkan dapat membantu dan memperlancar guru dan siswa dalam melaksanakan kegiatan belajar mengajar dalam kelas. Guru bukan saja sebagai sumber dari segala informasi. Namun, hal ini bukan berarti bahwa kegiatan pembelajaran tidak membutuhkan kehadiran guru. Siswa dituntut lebih aktif dalam pembelajaran didalam kelas, karena guru hanyalah fasilitator dalam pembelajaran sedangkan siswa harus lebih berperan aktif dalam pembelajaran. Kemasan bahan ajar ini berfungsi sebagai alat untuk mempermudah penyampaian materi yang akan diberikan guru kepada siswa dan dapat memudahkan siswa untuk memahami materi yang diajarkan. Dengan adanya bahan ajar elektronika ini diharapkan dapat meningkatkan kualitas pembelajaran untuk mencapai tujuan pembelajaran (Abdillah 2010).

Pengembangan bahan ajar berbasis budaya lokal perlu dilakukan dengan memenuhi standar pengembangan secara ilmiah. Hal ini didukung oleh Wahyudin (dalam Laksana, dkk 2015) yang menyatakan bahwa pengembangan aktivitas pembelajaran berbasis nilai budaya lokal memberikan kontribusi positif untuk meningkatkan literasi siswa berbasis kompetensi. Integrasi nilai budaya lokal dalam pengembangan kurikulum seperti membuat tujuan belajar, merancang bahan belajar, menentukan strategi pembelajaran, media belajar, dan evaluasi pembelajaran adalah penting dilakukan untuk kualitas pembelajaran (Northcote) (dalam Laksana, dkk 2015).

Duncan (dalam Laksana, dkk 2015) dalam penelitiannya menyatakan bahwa pengalaman awal menjadi dasar dalam melaksanakan pembelajaran. Guru dengan budaya yang berbeda dengan siswa, lebih sulit dalam memberikan pengalaman belajar yang sesuai dengan konteks budaya. Temuan lain juga diuangkapkan oleh Laksana dan Wawe (2015) menyatakan bahwa pembelajaran IPA dengan bantuan media terutama media berbasis budaya lokal memperlihatkan hasil yang memuaskan. Aktivitas belajar meningkat yang disertai dengan penguatan pemahaman konsep IPA siswa. Dengan demikian kajian budaya lokal harus terintegrasi dalam bahan pembelajaran sebagai upaya dalam meningkatkan kualitas pembelajaran. Pembelajaran yang dilaksanakan dengan mengintegrasikan konten dan konteks budaya lokal mendapat respin positif dari siswa Riwu, dkk (2018)selain itu dalam penelitian tersebut tersebut ditemukan bahwa bahan ajar elektronik bermuatan multimedia yang berdasarkan konten dan kontek budaya lokal ada pada kategori sangat baik, sehingga layak digunakan pada siswa sekolah dasar kelas IV.

Bahan ajar elektronik ini dapat meningkatkan kemampuan berpikir kritis siswa, hal ini dibuktikan dengan penelitian yang dilakukan Rosida, dkk (2017) yang menyatakan bahwa penggunaan $e$-book interaktif cukup efektif menumbuhkan keterampilan berpikir siswa. Kemudian temuan lain yang dilakukan Basri, dkk (2013) yang menyatakan bahwa pengembangan media pembelajaran berbasis komputer dapat meningkatkan motivasi belajar siswa. Bahan ajar eletronik ini terbukti mudah untuk dibawah kemana-mana. Hal ini dibuktikan oleh penelitian yang dilakukan Handayani (2016) yang menyatakan bahwa bahan ajar elektonik ini dapat digunakan melalui perangkat telekomunikasi seperti notebook, laptop, handphone, dan tablet sehingga lebih mudah dibawah dan dipelajari kapanpun dan dimanapun.

Bahan ajar elaktronik bermuatan multimedia (teks, gambar dan video) ini dapat memotivasi siswa dalam belajar karena, mulitmedia yang dikembangkan dalam bahan ajar ini dapat menarik perhatian siswa untuk belajar. Hal ini dibuktikan dengan penelitian yang dilakukan Oka (2017) yang menyatakan bahwa bahan ajar berbasis CDT efektif dan signifikan serta mampu meningkatkan hasil belajar mahasiswa untuk mata kuliah multimedia.

Bahan ajar elektronik yang dikembangkan ini, materinya yang berkaitan dengan budaya-budaya lokal yang dapat meningkatkan motivasi dan hasil belajar siswa. Hal ini dibuktikan dengan penelitian yang dilakukan oleh (Laksana dan Widiastika 2016) yang menyatakan bahwa multimedia yang dikembangkan adalah multimedia tematik, yaitu tema Keberagaman Budaya Bangsaku, terdapat beberapa konten budaya daerah yang diintegrasikan kedalam multimedia antara lain tari daerah, lagu daerah, permainan tradisional alat musik tradisional, makanan tradisional dan pakaian tradisional, yang dapat meningkatkan motivasi dan hasil belajar.

\section{Simpulan}

Berdasarkan hasil penelitian dan pembahasan yang telah dipaparkan diatas maka dapat ditarik kesimpulan bahwa (1) dapat dihasilkan bahan ajar elektronik bermuatan multimedia pada tema indahnya kebersamaan yang sesuai dengan karakteristik siswa sekolah dasar kelas IV yang dikembangkan dengan menggunakan model ADDIE. (2) Kualitas hasil uji produk Pengembangan bahan ajar elektronik bermuatan multimedia pada tema indahnya kebersamaan pada siswa sekolah dasar kelas IV yang dikembangkan, dilakukan uji coba oleh ahli desain ada pada kategori sangat baik, uji coba oleh ahli multimedia ada pada kategori baik, uji coba oleh ahli konten ada pada kategori baik, dan uji coba oleh siswa ada pada kategori sangat baik. Dengan demikian berdasarkan hasil uji coba bahan ajar elektronik oleh ahli dan siswa sebagai pengguna produk dinyatakan layak untuk digunakan dalam proses pembelajaran.

\section{Daftar Pustaka}

Abdillah, A.N. (2010). Konsep bahan ajar elektronik dan ciri / karakteristik bahan ajar elekronik. Diterima melalui https://sites.google.com>elearningtp2010. 
Dasna, I.W., Laksana, D.N.L., \& Sudatha I.G.W. (2015). Desain dan model pembelajaran inovatif dan interaktif. Tangerang Selatan: Universitas Terbuka.

Depdiknas. (2003). Sistem pendidikan Nasional. Jakarta: Depdiknas.

Laksana, D.N.L., \& Seso, M.A. (2018). Desain pembelajaran kontekstual spirit meda mazi di SD kelas rendah. Journal of Education Technology, 2(1), 1-5.

Laksana, D.N.L., \& Widiastika, I.G. (2017). Pengembangan multimedia pembelajaran tematik sekolah dasar berbasis budaya lokal masyarakat Flores. Jurnal Pendidikan Dasar Nusantara, 2(2), 150-160.

Laksana, D.N.L., Kurniawan, P.A.W., \& Niftalya, I. (2016). Pengembangan bahan ajar tematik SD kelas IV berbasis kearifan lokal masyarakat Ngada. Jurnal Ilmiah Pendidikan Citra Bakti, 3(1), 1-10.

Laksana, D.N.L., \& Wawe, F. (2015). Penggunaan media berbasis budaya lokal dalam pembelajaran IPA untuk meningkatkan aktivitas dan pemahaman konsep IPA siswa sekolah dasar. Jurnal Ilmiah Pendidikan Citra Bakti, 2(1), 27-37.

Oka, G.P.A. (2017). Pengembangan bahan ajar interaktif berbasis component display theory (CDT) pada mata kuliah multimedia jurusan teknologi pendidikan FIP UNDIKSHA. Jurnal IMEDTECH, 1(1), 46-58.

Prayogo, D.P. (2015). Pengembangan multimedia interaktif tematik untuk siswa kelas IV SD Muhammadiyah Condongcatur. Skripsi. Fakultas Ilmu Pendidikan: Universitas Yogyakarta.

Riwu, I.U., Laksana, D.N.L., \& Dhiu, K.D. (2018). Pengembangan bahan ajar elektronik bermuatan multimedia pada tema peduli terhadap makhluk hidup untuk siswa SD Kelas IV di Kabupaten Ngada. Journal of Education Technology, 2(2), 56-64.

Rosida, F.N., \& Jamlo, T. (2017). Efektivitas penggunaan bahan ajar e-book interaktif dalam menumbuhkan keterampilan berpikir kritis siswa. Jurnal Pembelajaran Fisika, 5(1). 